\title{
Decreasing poverty through the application of social entrepreneurship
}

\section{Muyassarzoda FAYZIEVA ${ }^{1}$, Mariya BEKIMBETOVA ${ }^{2}$}

Tashkent State University of Economics

\begin{tabular}{l} 
ARTICLE INFO \\
\hline Article history: \\
Received October 2021 \\
Received in revised form \\
15 October 2021 \\
Accepted 20 November 2021 \\
Available online \\
15 December 2021
\end{tabular}

\section{Keywords:}

social entrepreneurship, poverty reduction, social protection of population, social innovation, social enterprise, social project, social services.

\begin{abstract}
This article is devoted to assessing the impact of the development of social entrepreneurship on poverty reduction. Theoretical views and approaches in conceptual studies related to social entrepreneurship and poverty reduction are analyzed. The relationship between social entrepreneurship and poverty reduction has been studied by conducting a survey, developing scientifically based proposals and recommendations based on the results of the study to reduce poverty in Uzbekistan, through the development of social entrepreneurship.
\end{abstract}

2181-1415/C) 2021 in Science LLC.

DOI: https://doi.org/10.47689/2181-1415-vol2-iss11/S-pp249-259

This is an open access article under the Attribution 4.0 International (CC BY 4.0) license (https://creativecommons.org/licenses/by/4.0/deed.ru)

\section{Ижтимоий тадбиркорликни қўллаш орқали қашшоқликни камайтириш}

\footnotetext{
Калит сўзлар:

ижтимоий тадбиркорлик, камбағалликни қисқартириш, ахолини ижтимоий химоя қилиш, ижтимоий инновациялар, ижтимоий корхона, ижтимоий лойиха, ижтимоий хизматлар.
}

\begin{abstract}
АННОТАЦИЯ
Ушбу мақола ижтимоий тадбиркорликни ривожлантиришнинг камбағаллик даражасини камайтиришга таъсирини бахолашга қаратилган бўлиб, унинг мақсади ижтимоий тадбиркорлик ва камбағалликни қисқартириш масалаларига тааллуқли концептуал тадқиқотлардаги назарий қарашлар ва ёндашувларни ўрганиш, сўровнома орқали ижтимоий тадбиркорлик ва камбағаллик даражасини камайтириш ўртасидаги боғлиқликни аниқлаш, тадқиқот натижалари асосида ижтимоий тадбиркорликни ривожлантириш орқали мамлакатда камбағаллик даражасини камайтириш бўйича илмий асосланган таклиф ва тавсиялар ишлаб чиқишдан иборат.
\end{abstract}

\footnotetext{
${ }^{1}$ Assistant of the department of HRM, Tashkent State University of Economics. Tashkent, Uzbekistan.

E-mail: fayzievamuyassar87@gmail.com.

${ }^{2}$ Assistant of the department of Management, Tashkent State University of Economics. Tashkent, Uzbekistan.

E-mail: mariya.bekim@gmail.com.
} 


\section{Сокращение уровня бедности с помощью применения социального предпринимательства}

\author{
Ключевые слова: \\ социальное \\ предпринимательство, \\ сокращение бедности, \\ социальная защита \\ населения, \\ социальные инновации, \\ социальное предприятие, \\ социальный проект, \\ социальные услуги.
}

\section{АННОТАЦИЯ}

Данная статья, посвящена оценке влияния развития социального предпринимательства на сокращение уровня бедности. Проанализированы, теоретические взгляды и подходы в концептуальных исследованиях, связанные с социальным предпринимательством и сокращением уровня бедности. Изучена связь, между социальным предпринимательством и сокращением бедности путем проведения опроса, разработки по результатам исследования научно обоснованных предложений и рекомендаций по снижению уровня бедности в Узбекистане, путем развития социального предпринимательства.

\section{INTRODUCTION}

Poverty is one of the main challenges in global economic development. United Nations has reported that around 1.3 billion people around the world are multidimensional poor that not only means low income but also another number of indicators such as poor quality of life, poor health, and low-quality education (Wu and $\mathrm{Si}$, 2018). In recent decades, awareness that economic growth alone cannot bring prosperity to all citizens of a country has been growing. The current economic crisis in many EU countries has further strengthened trends for consideration of alternative models of economic development (Maji, 2016). In this context, the issue of social protection of the population has always been in the spotlight of the world, and today this issue is still of great importance in Uzbekistan. However, today's period requires new approaches to solving problems of social significance, and the development of social protection policies in the country using international experience. Particularly during the COVID-19, the protection of public health, employment, access to education, declining incomes, as well as the emergence of socio-economic problems associated with migration processes have increased the level of importance of the issue in countries around the world. The COVID19 pandemic has caused a variety of social problems, especially an increase in poverty among citizens with low daily incomes or no daily incomes at all. Thaha (2020) state that the COVID-19 pandemic impact shows that people do not have a daily income and that there have been significant job cuts (Thaha, 2020).

According to Social Change Central (2021) in world practice, socially oriented activities of legal entities or individual entrepreneurs aimed at alleviating or solving certain social problems of the population and their consequences are carried out through social entrepreneurship. To make such activity more understandable, it can be called a non-state social protection tool. The research conducted by the experts of the Center for Social Change (Social Change Central) is noteworthy in this regard. According to Center, one in four of the business entities created annually in the EU countries are social entrepreneurship entities. Social enterprises in the UK form about $5 \%$ of all enterprises (about 70,000 social enterprises), and employ almost 1 million people. A similar situation can be observed in Arab countries, where $20-30 \%$ of those who apply for state registration intend to establish social entrepreneurship. Even in African countries, $20 \%$ of those who 
want to start a business plan to engage in social entrepreneurship. There are also more than 20,000 social businesses in Australia and it can be observed that their weight has increased by 35 per cent in the last five years. The share of this sector in the country's GDP is $2-3 \%$.

Although the term "social entrepreneurship" is rarely used in our language, it is one of the most widely used and legally established principles in the world. For example, relations related to social entrepreneurship are reflected in the legislation of Korea, Italy, Great Britain, Belgium, Poland, the USA, China, and other countries, and a specific model of cooperation between the state and business entities in addressing social issues has been formed.

As mentioned by Rashidova (2020), who is a researcher in the field of social entrepreneurship, social entrepreneurship is a socially-oriented business in which income is not used to increase the income of business owners. The main purpose of such entrepreneurial activity is social utility, in which the focus is not on net profit, but on positive social change, the solution of human problems that are not solved by public social policy or business. The work of such enterprises mainly involves people who are socially unstable or have disabilities. At the same time, these enterprises will specialize in the production of socially useful goods and products (Rashidova, 2020). In such cases, the subject of social entrepreneurship considers the interests of society as a priority in its activities. Employ as many vulnerable groups as possible, produce or support special products for the disabled and the elderly, and be proactive in improving living standards.

In accordance with the current legislation of Uzbekistan, benefits are created for the creation of jobs for the socially vulnerable population, taxes and other types of enterprises that produce products and equipment for people with disabilities. However, the current legislation does not clearly define the legal concept of "social entrepreneurship" and the mechanisms of legal regulation of relations related to social entrepreneurship.

Improving the living standards of the socially vulnerable population by providing them with jobs, social goods and social services, selling social goods and socially important products at their own cost or at prices below cost, the conversion of business entities into the production of goods (works, services) aimed at the elimination of emergencies, the implementation of activities for other social purposes. For the above purposes, the draft Law of the Republic of Uzbekistan "On Social Entrepreneurship" in 2020 was published and included in this draft state support of social entrepreneurship by Chapter 4. Referring to the draft, social entrepreneurship will be supported by the state in the form of benefits and preferences, subsidies for social project costs, placement of the state social order, financial support, training, retraining and advanced training of social enterprise employees and others. This Law and its purpose are relevant in supporting the socially vulnerable groups of society, not only such categories, but all categories of society in the event of the COVID-19 pandemic and similar emergencies, which began a year and a half ago. If we look at social entrepreneurship as a new mechanism for employment, it is clear that this mechanism will provide employment for many unemployed people in society, and, as a result, will lead to major changes, such as poverty reduction, which is a pivotal issue in our country. 


\section{LITERATURE REVIEW}

\subsection{Social entrepreneurship}

Social entrepreneurship involves the recognition, evaluation, and exploitation of opportunities that result in social value - the basic and long-standing needs of society - as opposed to personal or shareholder wealth (Austin et all., 2006). Social entrepreneurship creates new models for the provision of products and services that cater directly to basic human needs that remain unsatisfied by current economic or social institutions (Seelosa and Mair, 2005).

Social entrepreneurship is a for-profit enterprise that has the dual goals of achieving profitability and attaining beneficial social returns. Rather than the usual entrepreneurship organization, social entrepreneurship is looked into as ray of hope to help those below the poverty line to live a better life in the future. The effectiveness of such social entrepreneurship in achieving the organizations' goals and their efficiency in their financing will further enhance their impact towards eradicating urban poverty (Mariotti and Glackin, 2013). SE is a structure that allows individuals to strike their own balance between the desire to make a social contribution and the personal need to capture an economic return from professional activity, across a wide range of possible ratios (Seelos and Mair, 2004).

Table 1.

\section{Comparison of Social Entrepreneurs and Commercial Entrepreneurship}

\begin{tabular}{|c|c|c|}
\hline Indicator & Social Entrepreneurs & Commercial Entrepreneurship \\
\hline Market failure & $\begin{array}{c}\text { Judging from the condition of social } \\
\text { organization with the birth of market } \\
\text { failure from several social aspects. }\end{array}$ & $\begin{array}{c}\text { Market pressures sometimes do } \\
\text { not match the expectations of } \\
\text { public needs. }\end{array}$ \\
\hline Mission & $\begin{array}{c}\text { The main target of a social } \\
\text { entrepreneur is social value for society. }\end{array}$ & $\begin{array}{c}\text { Its main target is to make a profit } \\
\text { as a result of its business activities. }\end{array}$ \\
\hline Resource Mobilization & $\begin{array}{c}\text { The challenge is a surplus of resources, } \\
\text { constrained to compensate, } \\
\text { competitive. More on value than on } \\
\text { material. }\end{array}$ & $\begin{array}{c}\text { There is a material compensation } \\
\text { to make it easier to pay } \\
\text { accordingly. }\end{array}$ \\
\hline Performance \\
Measurement & $\begin{array}{c}\text { Social changes are not easy to measure, } \\
\text { resulting in impacts that are difficult to } \\
\text { quantify. }\end{array}$ & $\begin{array}{c}\text { Performance standards are clear } \\
\text { and measurable. }\end{array}$ \\
\hline
\end{tabular}

Based on Austin (2003), Table 1 describes the difference between social entrepreneurship and business entrepreneurship (Austin, 2003).

\subsection{Poverty}

Poverty is a critical issue for the world with the numbers of people living at the base of the pyramid declining only slightly over time (Bruton, 2013). Poverty is the inability of individuals, households or an entire community to command sufficient resources to satisfy a socially acceptable minimum standard of living (May, 1999). Poverty is multidimensional; it affects the society in various ways, robs people of their dignity and limits their ability to improve their lives. It means not having access to basic human needs - such as food and clean water (Shirima, 2001). Poverty is dehumanizing; it is the most perceived motivator of most social vices. When any society alleviates or eliminates 
poverty, then, the fight against most of the societal problems is almost won. Poverty that arises mostly due to unemployment can be alleviated through entrepreneurship skill acquisition (Adofu et al., 2013).

\subsection{The relationship between social entrepreneurship and poverty reduction}

In the opinion of Rametse and Shah (2013), poverty-alleviation strategies based on social entrepreneurship seek to create societal value by identifying opportunities and

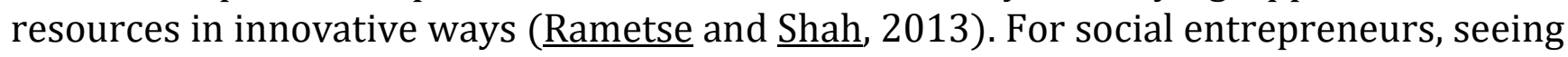
opportunities means seeing social problems and then continuing to think creatively to solve problems for the sake of community welfare (Rijal, 2019). Social entrepreneurs can provide the new approaches needed to hasten the process of reducing poverty and hunger. By combining innovative ideas from individuals and investments from public, private, and civil society organizations, such entrepreneurs can guide complex global food systems and rural institutions toward their goals (Suresh and Pinstrup-Andersen (2007).

Social entrepreneurs and their innovations for reducing poverty should not replace large-scale public-sector poverty intervention programs but rather enhance them with improved effectiveness (Suresh and Pinstrup-Andersen, 2007). A review by Cooney and Shanks (2010) of the empirical research on effectiveness of 'new' approaches (including social enterprise) to poverty alleviation found an emphasis on organizational sustainability and mission risk, with very little data on client outcomes. The one exception they noted was the work done by EMES in the EU to estimate the effects of participation in SEs on employment (Cooney and Shanks, 2010). The best cure for poverty alleviation in any region of the world lies in encouraging more business activity and startup the new ventures through entrepreneurship development. Moreover, entrepreneurship provides a basis for economic change through new knowledge creation and application (Singer, 2006). Subramanian and Mohanram (2016) found that innovation, family background, government support program, social entrepreneurship, women participation, entrepreneurship training \& education, individual entrepreneurial characteristics, participation of micro, small \& medium enterprises, youth empowerment, collaboration of government-university-industry is the key tool for entrepreneurship development which is stimulating employment are eventually alleviating poverty (Subramanian and Mohanram, 2016).

\section{RESEARCH METHODOLOGY}

The research design of this research is cross-sectional research design. The crosssectional research design is based on gathering information from participants at a specific point in time. The research survey was distributed on October 30th, 2021 via the Telegram social network, and responses were collected during a two-day period.

The research approach of this research is quantitative because the responses of respondents were reflected with percentages and numbers. The researchers aimed to analyze the answers of participants through Descriptive statistics, Frequencies and percentages analysis, the Reliability test, and Spearman's Correlation of the question items in order to determine overall perceptions of respondents.

The researchers applied both data collection methods. They include: primary data (based on this research's main results) and secondary data (annual reports, previous research papers in the social entrepreneurship field, and others). Over 50 research papers were viewed by the researchers and selected 27 research papers' findings and conclusions, 
as well as articles that are published on the Internet sites. The selected findings and conclusions which were already identified have been highlighted in the Introduction, Literature Review, and Results and Analysis sections of this research.

The data collection tool for this research is an online survey tool. The online survey was created in the form of two POLLs on the Telegram social network and distributed to an unlimited number of Telegram users on October 30th and 31th, 2021. The POLLs involve two question items which reflect on "The development of social entrepreneurship in our country is an important aspect of poverty reduction" and "Social entrepreneurship plays an important role in protecting the vulnerable population". Every question item consists of five options, and they include: "Strongly agree", "Agree", "I'm not sure", "Disagree", and "Strongly disagree". The measurement scale of these question options is an ordinal measurement scale.

The research analyzing software is JASP statistical software. The JASP software was used for analyzing the Descriptive statistics, Frequencies and percentages analysis, the Reliability test, and the Spearman's Correlation of the question items' options which were chosen by the research respondents.

\section{ANALYSIS AND RESULTS}

Many scientists and researchers have conducted research and studies on poverty reduction through social entrepreneurship, and these processes continue nowadays also. In international practice, the ways and means chosen by social entrepreneurs to reduce poverty are important, and it is worthwhile to cite a few of them in this research. For example, Martin Fisher and Nick Moon of Kickstart identified a socially entrepreneurial opportunity to build water pumps in Sub-Saharan Africa to provide better irrigation for subsistence farmers in the region (Fisher, 2006). The goal of creating this social enterprise is to reduce poverty by providing a mechanism that allows farmers in African countries to be more productive. In this case, social innovation is ancillary farming by increasing the productivity of existing agricultural lands. Social innovation - the fourth aspect of social value creation is social innovation, which highlights creating social value by employing fewer resources to achieve higher outcomes and solving insoluble problems. Innovation here refers to combining existing elements in a new way in the life of the disadvantaged group rather than in the organizations. An example is the initiatives of the International Development Enterprise in India that have brought the cheap, simple, durable technology of water pumps to the lives of poor farmers and have helped them to reduce their agricultural costs and earn more money (Young, 2008). Social value has little to do with profits but instead involves the fulfillment of basic and long-standing needs such as providing food, water, shelter, education, and medical services to those members of society who are in need (Certo and Miller, 2008).

Next example is Durojaye Mobile Toilet (DMT) which was established in Lagos in 1999 and seeks to transform the economic and environmental health of Nigerian. Nicknamed "Mr Shit", Durojaiye is transforming public hygiene in Africa in no small way. This social enterprise produces, hires out and maintains portable toilets, promoting sanitation and creating job opportunities for the unemployed youths. In 2010 and 2013, it became abundantly clear that shit business has become a big business in Nigeria and extending to other poor African countries (Deborah, 2014). 
Another example is "The Specialists" which is a for-profit consultancy firm from Denmark that usually and exclusively hires autistic people. The entrepreneur ensures that more people with autism will be more likely to have employment in the firm (Tanchangya et. Al., 2020).

In identifying innovative solutions to social problems through social entrepreneurship, the following individuals' innovative ideas play a major role regarding local government officials in the regions, deputies of local councils, the potential of business leaders, and other institutional leaders. Factors such as young people's involvement in public affairs, indifference to social problems, thorough mastery of modern information technologies, knowledge of several foreign languages, ability to see old problems in new ways, both in their social business sector and in promoting social entrepreneurship among society allows social problems to be active and proactive in the process of creating successful social innovative ideas as well. The recent establishment of Youth Institutions by the International Youth Foundation in several developing countries is aimed at developing young people as social entrepreneurs through leadership training that promotes social entrepreneurship.

One way to address poverty in developing countries is to apply business development principles to social problems. At the same time, social entrepreneurs use business principles in the implementation of social innovations. There are three types of such entrepreneurs, the first category of which are business leaders who are successful in their fields and whose entrepreneurial ability can help solve social problems. Entrepreneurs in the second category of them consider people from the socially vulnerable as potential consumers of their products and services. The third category is the part of the poor whose income, resource ownership, social capital and levels of entrepreneurship vary. Some become business-oriented social entrepreneurs with little financial support or training. Microfinance programs allow the poor and vulnerable to grow their businesses so that they can find innovative solutions to their social problems. For example, the emergence of private schools in response to unsatisfactorily managed public schools in India, Kenya, and Nigeria shows that poor people can find acceptable solutions to their social problems. The success of poverty reduction programs depends on the skills and abilities of program managers and local leaders.

The following statistical analyses were used by the researchers in order to find the main findings of this research:

\subsection{Descriptive statistics}

Table 2.

\section{Descriptive Statistics of research questions}

\begin{tabular}{|c|c|c|c|c|c|c|c|c|c|}
\hline $\begin{array}{l}\text { Soc_Entr_ } \\
\text { pover_reduc }\end{array}$ & N & 0 & \begin{tabular}{l}
8 \\
8 \\
$\circ$ \\
\hdashline
\end{tabular} & $\begin{array}{l}\circ \\
\text { ᄋ } \\
\\
+\end{array}$ & $\stackrel{F}{\overparen{r}}$ & $\begin{array}{l}9 \\
\stackrel{0}{0} \\
0\end{array}$ & 은 & ᄋ & $\begin{array}{l}\text { ○ } \\
\text { ம் }\end{array}$ \\
\hline $\begin{array}{c}\text { Soc_entrep_pro } \\
\text { tec_vul_popul }\end{array}$ & $\stackrel{0}{\stackrel{0}{N}}$ & $\stackrel{-}{N}$ & $\begin{array}{l}8 \\
8 \\
0 \\
\end{array}$ & $\begin{array}{l}8 \\
8 \\
\\
\end{array}$ & $\begin{array}{l}\infty \\
\infty \\
\text { ஸे } \\
\text { m. }\end{array}$ & 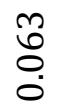 & 冓 & ᄋ̊요 & $\begin{array}{l}\text { ᄋ } \\
\text { ○. }\end{array}$ \\
\hline
\end{tabular}


Based on Table 2, it is clear that the first question item (Social entrepreneurship is an important aspect of poverty reduction) was given perceptions by 277 respondents, and the mean is 3.7, while at the same time, the mode and median are both 4.0. The second question item (Social entrepreneurship plays an important role in protecting the vulnerable population) was given perceptions by 256 respondents ( 21 were missed) and the mean is just below 4.0. The Mode and Median's indexes are the same with the first question item, which are 4.0.

\subsection{Frequency and percentages analysis}

Table 3.

Frequencies for question item "The development of social entrepreneurship in our country is an important aspect of poverty reduction"

\begin{tabular}{ccccc}
\hline Soc_Entr_pover_reduc & Frequency & Percent & Valid Percent & Cumulative Percent \\
1 & 16 & 5.776 & 5.776 & 5.776 \\
2 & 28 & 10.108 & 10.108 & 15.884 \\
3 & 54 & 19.495 & 19.495 & 35.379 \\
4 & 101 & 36.462 & 36.462 & 71.841 \\
5 & 78 & 28.159 & 28.159 & 100.000 \\
Missing & 0 & 0.000 & & \\
Total & 277 & $\mathbf{1 0 0 . 0 0 0}$ & & \\
\hline
\end{tabular}

According to Table 3, overall, 277 participants responded to the first question item, and among those, 101 chose the "Agree" option and 78 chose the "Strongly agree" option. "Strongly disagree" and "Disagree" options were chosen by 16 and 28 participants, respectively.

Table 4.

Frequencies for question item "Social entrepreneurship plays an important role in protecting the vulnerable population"

\begin{tabular}{ccccc}
\hline Soc_entrep_protec_vul_popul & Frequency & Percent & Valid Percent & Cumulative Percent \\
1 & 10 & 3.610 & 3.906 & 3.906 \\
2 & 11 & 3.971 & 4.297 & 8.203 \\
3 & 38 & 13.718 & 14.844 & 23.047 \\
4 & 110 & 39.711 & 42.969 & 66.016 \\
5 & 87 & 31.408 & 33.984 & 100.000 \\
Missing & 21 & 7.581 & & \\
Total & $\mathbf{2 7 7}$ & $\mathbf{1 0 0 . 0 0 0}$ & & \\
\hline
\end{tabular}

According to Table 4, overall, 256 participants replied (21 were missed) for the second question item and among 110 of all participants chose the "Agree" option and 87 participants chose the "Strongly agree" option. "Strongly disagree" and "Disagree" options were chosen by 10 and 11 participants. 


\subsection{The Reliability test}

Table 5.

\section{Bayesian Scale Reliability Statistics for research questions}

\begin{tabular}{cc}
\hline Estimate & Cronbach's $\alpha$ \\
Posterior mean & 0.970 \\
95\% CI lower bound & 0.962 \\
95\% CI upper bound & 0.977 \\
\hline Note. Of the observations, pairwise complete cases were used. \\
\hline
\end{tabular}

The researchers applied the Bayesian Unidimensional Reliability test to identify the reliability of gathered data for the research. In accordance with Table 5, it can be clear that the reliability of the survey is 0.970 , which means that the internal consistency of the survey is excellent. Based on the table's 95\% CI (Confidence Interval) lower and upper bounds, there is a $95 \%$ chance that the posterior mean of Cronbach's Alpha will be between 0.962 and 0.977 . There is a 5\% chance that the posterior mean of Cronbach's Alpha lays outside of the upper and lower confidence interval.

\subsection{Correlation}

Table 6.

\section{Spearman's Correlations of the research questions}

\begin{tabular}{|c|c|c|c|c|}
\hline Soc_Entr_pover_reduc & - & Soc_entrep_protec_vul_popul & $\begin{array}{c}\text { Spearman's rho } \\
0.935\end{array}$ & $\begin{array}{c}\mathbf{p} \\
<.001\end{array}$ \\
\hline Note. All tests one-taile & & ive correlation & & \\
\hline
\end{tabular}

With regard to the Spearman's Correlation coefficient of the research questions, there is a very strong and positive relationship between two question items in accordance with Table 6 ( $r=0.935, \mathrm{p}=.001$, Figure 1$)$.

\section{Figure 1. A Scatter Plot of the research questions}

\section{CONCLUSION AND RECOMMENDATIONS}

According to the main findings of this research, the researchers came to the following conclusion:

Based on results, it is identified that social entrepreneurship is an important aspect of poverty reduction in Uzbekistan. Social entrepreneurship plays one of the main means of protecting the vulnerable population in Uzbekistan.

In accordance with the above conclusion, the researchers have developed several science-based proposals and recommendations. They include:

- Creation of an appropriate legal framework that is the basis for the support of social business;

- Establishment of a department (s) to support social enterprises (or social business) and social entrepreneurship in the organizational system of the responsible ministry; 
- Establishment of a fund to support social entrepreneurship, allocation of funds for self-employment activities for the poor and vulnerable groups, as well as for the establishment and operation of social enterprises dealing with various social issues;

- Implementation of research and projects related to the creation of the social business sector;

- Organization of effective activities (leadership training) by the Youth Union of Uzbekistan and the Agency for Youth Affairs to promote and direct social entrepreneurship among young people;

- Training of specialists on social entrepreneurship (social enterprise, social business, social innovation, etc.) in secondary special and higher education institutions;

- Preparation of textbooks "Social Entrepreneurship" for students of secondary special and higher education institutions;

- Creation and development of the Institute of Social Entrepreneurship;

- Holding the traditional annual republican forum of social entrepreneurs.

\section{REFERENCES:}

1. Adofu I., Ocheja A., Abula M. (2013). Alleviating Poverty through the Use of Entrepreneurship Skill Acquisition in Kogi State, Nigeria. Aceh International Journal of Social Sciences, 2 (1): 01 - 10 June 2013.

2. Austin J., Stevenson H., Wei-Skillern J. (2006). Social and commercial entrepreneurship: Same, different, or both? Entrepreneurship Theory and Practice, 30(1), 1-22.

3. Austin J., Stevenson H., Wei-Skillern J. (2003). Social entrepreneurship and commercial entrepreneurship: same, different, or both? Division of Research, Harvard Business School.

4. Bruton G.D., Ketchen Jr., Duane Ireland R. (2013). Entrepreneurship as a solution to poverty. Journal of Business Venturing.

5. Cooney K., Shanks T. (2010). New Approaches to Old Problems: Market-Based Strategies for Poverty Alleviation. Social Service Review 84 (1): 29-55.

6. Deborah D. (2014). Social Enterprises: can it succeed? Retrive from www.the Guardian com on 3/5/2014.

7. Fisher M. (2006). Income is development. Innovations, 1, 9-30.

8. Ibragimova M. (17.12.2020). Ижтимоий тадбиркорлик - мамлакатимизда нодавлат ижтимоий химоя сиёсатини ривожлантириш йўлидаги муқим қадам. https://xs.uz/uzkr/post/izhtimoij-tadbirkorlik-mamlakatimizda-nodavlat-izhtimoijhimoya-siyosatini-rivozhlantirish-jolidagi-muhim-qadam.

9. MAJI A., Adejoh D. (2016). Exploring the Potentials of Social Enterprises for Poverty Alleviation in Nigeria and Cameroon in the 21st Century. European Journal of Business and Management www.iiste.org. Vol. 8. - No.28. - 2016.

10. Mariotti S., Glackin C. (2013). Entrepreneurship Starting and Operating a Small Business. New Jersey: Pearson Education.

11. May J. (1999). Poverty and Inequality in South Africa: Meeting the Challenge. D. Philip, Cape Town.

12. Rametse N., Shah H. (2013). Investigating Social Entrepreneurship in Developing Countries. World Review of Business Research, Vol. 3. - No. 2. March 2013 Issue. PP. 95-112. 
13. Rashidova M. (05.05.2020). Ижтимоий тадбиркорлик жамиятдаги ижтимоий муаммоларни хал қиладими? https://xdp.uz/partiya-yangiliklari/1323.

14. Rijal S., Haerani Y., Mayasari R.E., Yusriadi Y. (2019). The Effectiveness of Implementation of Government Regulation Number 41 The Year 2011 On The Development Of Youth Entrepreneurship And Pioneering And The Provision Of Youth Facilities And Infrastructures In Kolaka. International Journal of Scientific \& Technology Research, 8(10). http://www.ijstr.org/paperreferences.php?ref=IJSTR-1019-22680.

15. Seelos Ch., Mair J. (2005). Social entrepreneurship: Creating new business models to serve the poor. Business Horizons (2005) 48, 241-246.

16. Seelos Ch., Mair J. (2004). Social entrepreneurship: The contribution of individual entrepreneurs to sustainable development. IESE Business School. Working Paper 553.

17. Singer A.E. (2006). Business strategy and poverty alleviation. Journal of Business Ethics, vol. 66, PP. 225-231, 2006.

18. Shirima L.L. (2001). The Micro Impacts of the Expanded Oil Production in Angola: Simulation 2001 to 2010. Edited by the World Bank. World Bank. http://info.worldbank.org/etools/docs/Angola\%20Project.pdf.

19. Social Change Central. Social Enterprise: Statistics from Around the World. https://www.socialchangecentral.com/social-enterprise-statistics-from-around-the-world/.

20. Subramanian S.S., Mohanram V. (2016). Need for social entrepreneurship development - poverty alleviation tool. Roots International Journal of Multidisciplinary Researches A Peer Reviewed, Refereed \& Quarterly Journal Vol: 2. No: 4. May 2016. ISSN: 2349-8684 (ISRA - Impact Factor: 0.811).

21. Suresh B., Pinstrup-Andersen (2007). Social innovation and entrepreneurship Developing Capacity to Reduce Poverty and Hunger. October 2007, International Food Policy Research Institute.

22. Tanchangya P., Yingjing Chu., Hasan Chowdhury N. (2020). social entrepreneurs' role on poverty reduction through job creation. North American Academic Research, Volume 3, Issue 02; February, 2020; 3(02) 420-438.

23. Thaha, (2020). Dampak COVID-19 terhadap UMKM di Indonesia. BRAND Jurnal Ilmiah Manajemen Pemasaran, 2(1), 147-153. https://ejournals.umma.ac.id/index.php/brand.

24. Trevis Certo, S., Miller, T. (2008). Social entrepreneurship: Key issues and concepts. Business Horizons (2008) 51, 267-271.

25. Wu J. Si S. (2018). Poverty reduction through entrepreneurship: incentives, social networks, and sustainability. Asian Business \& Management, 17(4), PP. 243-259.

26. Young R. (2008). For what it is worth: Social value and the future of social entrepreneurship. In Social entrepreneurship: New models of sustainable social change, edited by Nicholls, A. 56-73. Oxford, New York: Oxford University Press. 